\title{
Capital Structure Management of Joint Venture Banks of Nepal
}

\author{
Sujata Timsina ${ }^{10}$
}

\begin{abstract}
This study entitled," Capital Structure Management of Joint Venture Banks of Nepal" has been conducted to examine whether the determinants of capital structure affect the leverage position of joint venture banks. Three joint venture banks have been selected for the study based on their similarities in assets size and age. The study intends to test the relationship between capital structure and profitability and evaluate the optimality of the capital structure of the banks. The main purpose of this study is to analyze and compare the capital structure management practices of three leading joint venture banks taken into consideration.
\end{abstract}

This study has been conducted with the secondary data obtained from the quarterly financial statements, annual publications of NRB and even from the official website of Nepal Stock Exchange. A linear regression model has been applied for analyzing the data. Six independent variables have been identified based on the standard determinants of capital structure. The variables include size, profitability, assets tangibility, liquidity, risk and growth. To determine the variables, previous studies particularly of Sailaja and Madhavi (2015), Singh and Tandon (2012) and Basnet (2015) have been consulted. Statistical and financial tools such as ratio analysis, correlation and regression analysis as well as inferential analysis have been used to analyze the quantitative data.

The researcher has been able to draw the conclusion that the regulatory requirements also affect the leverage position. In addition to these, factors that are significant to the capital structure of the three sample banks are size of the bank, profitability, liquidity and growth. The study has thus helped to find out strengths \& weaknesses of the joint venture banks. With these findings, the study might be helpful to drive the banks into the progressive track. Understanding these factors and their crucial relationships with leverage will help to maximize the value of the bank and minimize the overall cost of capital.

The study concludes that amongst the three joint venture banks taken into consideration, Everest Bank Limited is the better in terms of profitability, Himalayan Bank Limited is better in terms of stability and Nepal SBI Bank is more risk prone but has sufficient liquidity. Hence, the study shows that the

10 Ms. Timsina AIM iscurrently working in Loan Department of Laxmi Bank, Nepal. Corresponding email: naanisuja.2866@gmail.com 
standard determinants of capital structure are actually able to explain the variation in leverage of banks.

Keywords: Capital structure, joint venture banks, secondary data, descriptive and inferential analysis

\section{Introduction}

A joint venture is a business agreement in which the parties agree for a finite time to develop a new entity by contributing a portion of equity. In European terms, the term 'joint venture' is an elusive legal concept, better defined under the rules of company act. In Germany, 'joint venture' is better represented as a combination of companies' (Konzern).

Accenture's analysis of 158 global joint ventures in the banking industry between 2004 and 2012 reveals robust growth in such relationships. The survey in 2014 by Accenture shows $63 \%$ growth in overall venture-capital investments. In international context, joint venture arrangements were until recently relevant to regulating relationships between private parties to a project company in a BuildOwn-Transfer (BOT).

In context of Nepal, the performance of foreign joint venture banks is better than the domestic banks reflected in their profitability position. The shares of interest income to total income are lower in the joint venture banks. This indicates that the service business is better in those banks. At present there are 7 joint venture banks operating in Nepal which include Nepal SBI Bank, Everest Bank, NABIL Bank, Standard Chartered Bank, Nepal Bangladesh Bank, Himalayan Bank and NMB Bank.

The banking sector of Nepal has experienced a rapid change after the economic liberalization. Various joint venture foreign commercial banks are operating in Nepal after the HMG/N adopted the open, liberal and market oriented economic policy. However, the financial sector hasn't been responsive enough for them to meet the growing need of the economy as expected before. So, the main questions that need to be addressed are as follows:

- Why has not the financial sector been responsive and what are the problems behind it?

- Are the joint venture banks economically and financially sound?

To answer these questions, an analysis of the present capital structure of joint venture banks in Nepal has been done with reference to Nepal SBI Bank Ltd, Himalayan Bank Ltd (HBL) and Everest Bank Ltd (EBL) as they are similar in age as well as assets size. The main objective of this study is to analyze the 
determinants of capital structure and its relationship with the profitability and performance of the sample joint venture banks.

This paper has been organized in five parts. The first part includes introduction and the second part includes literature review. The third part includes methodology, fourth includes results/analysis and fifth includes the conclusion.

\section{Literature Review}

Some useful literatures related to capital structure management have been reviewed. The main purpose of reviewing these articles and journals is to gain an idea on the research studies conducted earlier and what remains to be done. This provides a foundation for developing comprehensive theoretical framework and hypotheses for testing.San, Heng (2011); this paper investigates the relationship of capital structure and corporate performance of firm before and during crisis (2007).

The main objective of the study is to identify the relationship between capital structure and corporate performance of firms in construction sector before and during crisis. The result shows that there is relationship between capital structure and corporate performance .Besides, there is also evidence which shows no relationship between the variables.

Singh and Tandon (2012); The present study is based on the analysis of five years annual reports of SBI and ICICI bank from 2005-06 to 2009-10. The main aim of present study is to comparatively analyze the capital structure of the banking industry with reference to SBI and ICICI bank. Other objectives are to examine the bank policy regarding capital structure and the effect of capital structure on the profitability of the companies in relation of various ratios.

After analyzing the capital structure ratios of State Bank of India and ICICI Bank, it is clear that capital structure consists of equity and debt funds. The dependence of State Bank of India on outsider fund is revealed from the study. However the dependence of ICICI Bank on owned fund is increasing continuously. The study concluded that both companies have the policy using trading on equity.

Sailaja and Madhavi (2015); This research aims to analyze the relationship between capital structure of the public and private sector banks and its profitability. The main objective of the study is to examine the effect of capital structure on bank's profitability. From the study, it can be concluded that in private sector banks capital structure decision influences earnings per share. It is also observed that in public sector banks capital structure affects the earnings per share as per the results showed in regression analysis. 
Similar studies have been done by Marimuthu (2009), Skopljak and Luo (2012), Velnampy and Niresh (2012), Aktar et.al (2015). Their main objective was to examine the relationship between capital structure and profitability of the sample banks.

Basnet (2015); This paper investigates the influence of bank specific and macroeconomic factors on capital structure choices.This study aims at testing whether standard determinants of capital structure affects the leverage position of financial firms. The paper concludes that standard determinants are actually able to explain the variation in leverage of banks. The regulatory requirements also affect the leverage position. However, this effect is much more evident for book leverage than market leverage. In addition to this, the factors that are significant in case of book leverage are profitability and dividend.

Similar studies on the impact of the determinants of capital structure on leverage of banks have been done by Hossain, Yakub (2014), Ahmeti et.al (2014), Aremu et.al (2013), Ajanthan (2013), Tamulyte (2012), Juca et.al (2012), Gropp and Heider (2009), Baral (2004), Aivazian (1999).

In context of joint venture banks, very limited studies have been done regarding their capital structure. Most of the research done on joint venture banks has been found to be based on their formation structure or their overall financial performance. This study adds to existing literature the effect of capital structure specifically on joint venture bank's performance in context of our country. A valid and full-fledged research in the joint venture banking sector has not yet been done

\section{The Methodology}

The various means of financing represent the financial structure of an enterprise. The term "capital structure" is made up of debt and equity securities which comprise a firm's finance of its assets. The determination of the degree of liquidity of a firm is no simple task. In the long run, liquidity may depend on the profitability of a firm; but whether it survives to achieve long-run profitability depends to some extent on its capital structure. 
This study tries to provide an insight into the major drivers of capital structure management of banks and financial institutions. Theories such as Net Income Approach, Net Operating Income Approach, Modigliani-Miler (MM) Approach and modern theories of capital structure such as pecking order theory and agency cost theory consider different determinants crucial for optimizing the capital structure. However, all these theories conclude on the same proposition of minimizing the overall cost and increasing the returns. This is possible through appropriate combination of debt and equity driven by factors such as size, growth, profitability, assets tangibility, liquidity and risk.

\section{1. Conceptual Model}

This study follows the approach of Singh and Tandon (2005) and Sailaja and Madhavi (2015) which has considered certain factors crucial in analyzing the capital structure of banks. Incorporating these factors, the conceptual framework for conducting the study is as follows:

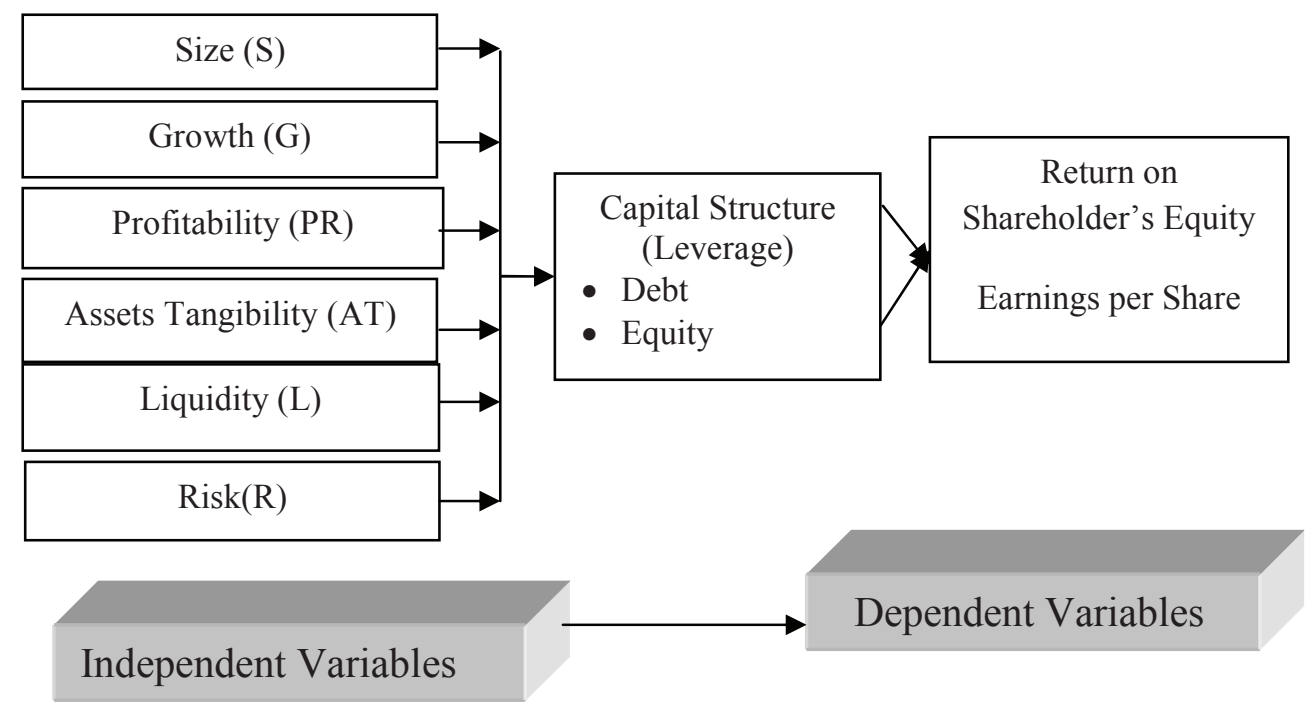

Figure 1. Conceptual Model

\subsection{Specification of Variables}

The dependent and independent variables considered for the study are based on the major determinants of capital structure of banks. The major determinants of capital structure have been extracted through several literature reviews. The variables are: 
Size of the firm: Size has been viewed as a determinant of a firm's capital structure. Larger firms are more diversified and hence have lower variance of earnings, making them able to tolerate high debt ratios (Basnet 2015).

Size $=$ Total Assets .

Assets Tangibility: The availability of more tangible assets decreases the bankruptcy cost as tangible assets are more liquid than intangible assets. In addition to this, the presence of fixed assets reduce the investigation cost during liquidation, making the process cheaper (Hossain and Yakub, 2014). Assets Tangibility $=$ Fixed Assets $/$ Total Assets .

Growth: The agency cost is likely to be higher for enterprises in growing industries which have more flexibility in their choice of future investment (Baral, 2004). Pecking order theory, however, shows the positive relation between the growth rate and debt level of enterprises.

\section{Growth $=$ Market to book value $=$ Price per share $/$ Book Value Per Share}

Liquidity: When firms have high liquidity, they might support relatively higher debt ratio due to the greater ability to meet short term obligations when they fall due (Ibrahim, 2014). It indicates positive relationship between a firm's liquidity position and capital structure.

\section{Liquidity $=$ Short term Assets $/$ Short term Liabilities}

Business Risk: Business risk is inversely related to leverage as the more the risk in the business, the less is its chance of raising its debt and deposits (Cebenoyan and Strahan, 2001). However, certain firms tend to raise more short term loans to help them in risky situations.

\section{Business Risk $=$ Percentage Change in Operating Income}

Total Debt:Short-term debts are those that must be paid back within a year. This type of debt applies to things like lines of credit or short-term term bonds (Velnampy and Niresh 2012).

Total Shareholder's Equity: TotalShareholder's equity is the share capital retained in the bank in addition to the retained earnings minus the treasury shares (Aktar,Parvin,Easmin 2015).

Profitability: The higher profitability of firm implies higher debt capacity and less risky to the debt holders (Ajanthan, 2013). The pecking order theory suggests that this relation is negative. 
Return on Shareholder's Equity: Return on equity measures a bank's profitability by revealing how much profit it generates with the money shareholders have invested (Aktar, Parvin, Easmin, 2015).

\section{ROE = Net Income/ Shareholder's Equity}

Earnings Per Share: Earnings Per Share (EPS) represents the portion of a bank's earnings, net of taxes and preferred stock dividends that is allocated to each share of common stock (Aktar, Parvin, Easmin, 2015).

\section{EPS $=$ Net Income after Taxes / Average Outstanding Shares}

\section{3. Determination of Sample Size}

This study covers only the financial aspects with secondary data of website of each bank which is assumed tobereliable and factual.The study uses six year's quarterly data of each bank which may not besufficient for the full-fledged study of this topic.The study is confined to the joint venture banks in the banking sector. Currently there are 7 joint venture banks in operation in Nepal with their branches located in different parts of the country. Out of the population of 7 joint venture banks, 3 joint venture banks have been selected as samples ,which comprise $43 \%$ of the total population of joint venture banks in Nepal. The Nepal SBI Bank Ltd, Himalayan Bank Ltd and Everest Bank Ltd banks havebeen selected as sample banks. These banks are taken into consideration as they are similar in age and assets size which facilitatesthe comparison.

\section{4. Data Analysis Methods}

This study is based on an applied research as existing theories and concepts have been applied to fulfill the objectives of the study. The data has been collected from secondary sources such as balance sheets, profit and loss accounts and cash flow statements from thefiscal year 2008/09 to 2013/14 (i.e. six years quarterly data comprising 24 data sets).The researcher has used analytical and descriptive study methods with the help of appropriate statistical or financial tools. The important financial and statistical tools, and methods used for the analysis are ratio analysis, descriptive statistics, Karl Pearson's correlation, econometric model, linear regression analysis. After going through several literature reviews and finalizing the major variables, secondary data was also collected and analyzed using MSExcel and SPSS. Linear regression has been used to test the theoretical relation between financial leverage and factors affecting capital structure of the firm. The data includes several independent factors affecting the capital structure for different firms. 


\section{Data Analysis and Interpretation}

Various measures such as ratio analysis, arithmetic mean, standard deviation, coefficient of correlation, testing of hypothesis, regression analysis etc. have been employed to analyze the position of the capital structure management of three sample joint venture banks.

The comparative analysis of capital structure management of the sample joint venture banks by using above tools can be presented, analyzed and interpreted as follows:

\subsection{Descriptive Statistics}

To provide simple summaries about the sample, descriptive measures used to describe the data sets are: central tendency and measures of variability or dispersion. Size, Growth, Profitability, Assets Tangibility, Liquidity, Risk are the major determinants of leverage. These are the independent variables considered for the study.

Table 1. Descriptive Statistics of EBL

\begin{tabular}{|l|l|l|l|l|}
\hline EBL & Minimum & Maximum & Mean & Std. deviation \\
\hline Asssets Tangibility & 0.88 & 9.69 & 1.48 & 1.76 \\
\hline Profitability & 1.73 & 2.39 & 2.06 & 0.18 \\
\hline Size & 31040731 & 72175693 & 49813131 & 12885231 \\
\hline Growth & 26.79 & 107.4 & 59.53 & 21.94 \\
\hline Liquidity & 24.92 & 36.45 & 31.42 & 3.84 \\
\hline Risk & -34 & 67 & 6.34 & 21.95 \\
\hline
\end{tabular}

Table 2. Descriptive Statistics of $\mathrm{HBL}$

\begin{tabular}{|l|l|l|l|l|}
\hline HBL & Minimum & Maximum & Mean & Std. Deviation \\
\hline Assets Tangibility & 1.76 & 2.99 & 2.32 & 0.33 \\
\hline Profitability & 1.01 & 2.14 & 1.62 & 0.33 \\
\hline Size & 38761684 & 74992922 & 52385537.1 & 11216440.8 \\
\hline Growth & 25.5442 & 102.22 & 46.4108425 & 18.28 \\
\hline Liquidity & 25.06 & 46.62 & 33.73 & 5.11 \\
\hline Risk & -45.48 & 77.36 & 8.12 & 35.08 \\
\hline
\end{tabular}

Table 3. Descriptive Statistics of NSBI

\begin{tabular}{|l|l|l|l|l|}
\hline NSBI & Minimum & Maximum & Mean & Std. Deviation \\
\hline Assets Tangibility & 0.77 & 1.32 & 1.024 & 0.15 \\
\hline Profitability & 0.76 & 2.65 & 1.24 & 0.43 \\
\hline Size & 19377475 & 64793964 & 47200282 & 13481872 \\
\hline Growth & 29.9 & 100.94 & 53.28 & 20.25 \\
\hline Liquidity & 28 & 57.1 & 39.98 & 9.63 \\
\hline Risk & -31.94 & 44.43 & 6.62 & 21.96 \\
\hline
\end{tabular}


Table 1, Table 2 and Table 3 show the minimum and maximum values, mean value and standard deviation of the three sample joint venture banks. The assets tangibility of EBL, HBL and NSBI are 1.48, 2.32 and 1.024 respectively. It seems that HBL has a larger portion of fixed assets in its total assets portfolio and thus has more liquidity. NSBI has the least tangibility of assets. However, the variation in the assets tangibility over the years is higher for EBL as compared to the other two banks. The average profitability of EBL is 2.06 which is higher as compared to that of HBL and NSBI. The average size of EBL, HBL and NSBI are 49813131, 52385537.1 and 47200282 respectively. This indicates that HBL has the largest size in terms of assets as compared to the other two banks. However, standard deviation of NSBI seems to be higher.

The average growth rate of EBL is 59.53 which is higher as compared to that of HBL and NSBI. Along with it, the standard deviation of growth of EBL is 21.94 which is the highest among the sample banks. Average liquidity of NSBI is 39.98 which is the highest compared to HBL and EBL which have a liquidity of 33.73 and 31.42 respectively. EBL has the least volatility in terms of liquidity as it has a standard deviation of 3.84 which is the lowest among the sample banks. In terms of risk, HBL seems to be riskier than EBL and NSBI with the highest value of 8.12.

\section{2. Hypothesis Testing}

$\left(\mathrm{HO}_{1}\right)$ : There is no significant relationship between leverage and assets tangibility of sample banks.

Table 4. Debt to Equity and Assets Tangibility of EBL

\begin{tabular}{|l|l|l|l|l|l|l|}
\hline & & \multicolumn{4}{|c|}{ Unstandardized Coefficients } & \multicolumn{3}{l|}{ Standardized Coefficients } \\
\hline Model & & B & Std. Error & Beta & t & Sig. \\
\hline 1 & (Constant) & 1275.337 & 44.59 & & 28.601 & 0.000 \\
\hline & Assets Tangibility & -4.39 & 19.637 & -0.048 & -0.224 & 0.825 \\
\hline
\end{tabular}

In table 4, relationship between debt to equity and assets tangibility of EBL is measured and the significance value is 0.825 which is greater than $0.05(0.825>0.05)$. This indicates that there is no significant relationship between debt to equity and assets tangibility as null hypothesis $\mathrm{H}_{1 \mathrm{a}}$ is accepted.

Table 5. Debt to Equity and Assets Tangibility of HBL

\begin{tabular}{|l|l|l|l|l|l|l|}
\hline & & \multicolumn{4}{|c|}{ Unstandardized Coefficients } & \multicolumn{3}{|c|}{ Standardized Coefficients } \\
\hline Model & & B & Std. Error & Beta & t & Sig. \\
\hline 1 & (Constant) & 876.457 & 101.69 & & 8.619 & 0 \\
\hline & Assets Tangibility & 94.321 & 44.33 & 0.413 & 2.128 & 0.045 \\
\hline
\end{tabular}

Table 5 measures the relationship between debt to equity and assets tangibility of $\mathrm{HBL}$ and as the significance value is 0.045 which is less than $0.05(0.045<0.05)$. 
This indicates that there exists significant relationship between debt to equity and assets tangibility as null hypothesis $\mathrm{H}_{1 \mathrm{~b}}$ is rejected.

Table 6. Debt to Equity and Assets Tangibility of NSBI

\begin{tabular}{|l|l|l|l|l|l|l|}
\hline & & \multicolumn{4}{|l|}{ Unstandardized Coefficients } & \multicolumn{3}{|c|}{ Standardized Coefficients } \\
\hline Model & & B & Std. Error & Beta & t & Sig. \\
\hline 1 & (Constant) & 1500.364 & 247.708 & & 6.057 & 0 \\
\hline & Assets Tangibility & 5.203 & 239.346 & 0.005 & 0.022 & 0.983 \\
\hline
\end{tabular}

Table 6 measures the relationship between debt to equity and assets tangibility of NSBI and since the significance value is 0.983 which is greater than $0.05(0.983>0.05)$, there exists no significant relationship between debt to equity and assets tangibility as null hypothesis $\mathrm{H} 0_{1 \mathrm{c}}$ is accepted.

$\left(\mathrm{HO}_{2}\right)$ : There is no significant relationship between leverage and profitability of sample banks.

Table 7. Debt to Equity and Profitability of EBL

\begin{tabular}{|l|l|l|l|l|l|l|}
\hline & & \multicolumn{4}{|l|}{ Unstandardized Coefficients } & \multicolumn{3}{l|}{ Standardized Coefficients } \\
\hline Model & & B & Std. Error & Beta & t & Sig. \\
\hline 1 & (Constant) & 2864.612 & 185.975 & & 15.403 & 0.000 \\
\hline & Profitability & -773.873 & 89.847 & -0.878 & -8.613 & 0.000 \\
\hline
\end{tabular}

In table 7, relationship between debt to equity and profitability of EBL is measured and the significance value is 0.000 which is less than $0.05(0.00<0.05)$. This indicates that there is significant relationship between debt to equity and profitability as null hypothesis $\mathrm{HO}_{2 \mathrm{a}}$ is rejected.

Table 8. Debt to Equity and Profitability of HBL

\begin{tabular}{|l|l|l|l|l|l|l|}
\hline & & \multicolumn{4}{|l|}{ Unstandardized Coefficients } & \multicolumn{3}{l|}{ Standardized Coefficients } \\
\hline Model & & B & Std. Error & Beta & t & Sig. \\
\hline 1 & (Constant) & 1179.048 & 77.183 & & 15.276 & 0.000 \\
\hline & Profitability & -55.982 & 47.901 & -0.242 & -1.169 & 0.255 \\
\hline
\end{tabular}

Table 8 shows the relationship between debt to equity and profitability of HBL and since the significance value is 0.255 which is greater than $0.05(0.255>0.05)$. So, there is no significant relationship between debt to equity and profitability as null hypothesis $\mathrm{H}_{2}$ is accepted.

Table 9. Debt to Equity and Profitability of NSBI

\begin{tabular}{|l|l|l|l|l|l|l|}
\hline & & \multicolumn{4}{|c|}{ Unstandardized Coefficients } & \multicolumn{3}{|c|}{ Standardized Coefficients } \\
\hline Model & & B & Std. Error & Beta & T & Sig. \\
\hline 1 & (Constant) & 1635.047 & 107.956 & & 15.146 & 0.000 \\
\hline & Profitability & -104.004 & 82.27 & -0.26 & -1.264 & 0.219 \\
\hline
\end{tabular}


In table 9 relationship between debt to equity and profitability of NSBI is measured and the significance value is 0.219 which is greater than $0.05(0.219>0.05)$. This indicates that there is no significant relationship between debt to equity and profitability as null hypothesis $\mathrm{H}_{2 \mathrm{c}}$ is accepted.

$\left(\mathrm{HO}_{3}\right)$ : There is no significant relationship between leverage and size of sample banks.

Table 10. Debt to Equity and Size of EBL

\begin{tabular}{|l|l|l|l|l|l|l|}
\hline & & \multicolumn{4}{|l|}{ Unstandardized Coefficients } & \multicolumn{3}{l|}{ Standardized Coefficients } \\
\hline Model & & B & Std. Error & Beta & t & Sig. \\
\hline 1 & (Constant) & 1771.152 & 82.082 & & 21.578 & 0.000 \\
\hline & Size & $-1.01 \mathrm{E}-05$ & 0 & -0.803 & -6.313 & 0.000 \\
\hline
\end{tabular}

In table 10, relationship between debt to equity and size of EBL is measured and the significance value is 0.000 which is less than $0.05(0.000<0.05)$. This indicates that there exists a significant relationship between debt to equity and size as null hypothesis $\mathrm{H}_{3}$ a is rejected.

Table 11. Debt to Equity and Size of HBL

\begin{tabular}{|l|l|l|l|l|l|l|}
\hline & & \multicolumn{4}{|l|}{ Unstandardized Coefficients } & \multicolumn{3}{|l|}{ Standardized Coefficients } \\
\hline Model & & B & Std. Error & Beta & t & Sig. \\
\hline 1 & (Constant) & 1260.409 & 67.578 & & 18.651 & 0.000 \\
\hline & Size & $-3.24 \mathrm{E}-06$ & 0 & -0.48 & -2.567 & 0.018 \\
\hline
\end{tabular}

Table 11 measures the relationship between debt to equity and size of HBL and as the significance value is 0.018 which is less than $0.05(0.018<0.05)$. So, there is significant relationship between debt to equity and size as null hypothesis $\mathrm{H}_{3 \mathrm{~b}}$ is rejected.

Table 12. Debt to Equity and Size of NSBI

\begin{tabular}{|l|l|l|l|l|l|l|}
\hline & & \multicolumn{4}{|l|}{ Unstandardized Coefficients } & \multicolumn{3}{l|}{ Standardized Coefficients } \\
\hline Model & & B & Std. Error & Beta & t & Sig. \\
\hline 1 & (Constant) & 1568.2 & 131.629 & & 11.914 & 0 \\
\hline & Size & $-1.32 \mathrm{E}-06$ & 0 & -0.105 & -0.493 & 0.627 \\
\hline
\end{tabular}

In table 12, relationship between debt to equity and size of NSBI is measured and the significance value is 0.627 which is greater than significance value $(0.627>0.05)$. This indicates that there is no significant relationship between debt to equity and size as null hypothesis $\mathrm{H}_{3 \mathrm{c}}$ is accepted. 
Null Hypothesis $\left(\mathrm{HO}_{4}\right)$ : There is no significant relationship between leverage and growth of sample banks.

Table 13. Debt to Equity and Growth of EBL

\begin{tabular}{|l|l|l|l|l|l|l|}
\hline & & \multicolumn{4}{|c|}{ Unstandardized Coefficients } & \multicolumn{3}{|c|}{ Standardized Coefficients } \\
\hline Model & & B & Std. Error & Beta & t & Sig. \\
\hline 1 & (Constant) & 1051.071 & 86.448 & & 12.158 & 0.000 \\
\hline & Growth & 3.658 & 1.366 & 0.496 & 2.678 & 0.014 \\
\hline
\end{tabular}

Table 13 shows the relationship between debt to equity and growth of EBL and the significance value is 0.014 which is less than $0.05(0.014<0.05)$. This indicates that there is significant relationship between debt to equity and growth as null hypothesis $\mathrm{HO}_{4 \mathrm{a}}$ is rejected.

Table 14. Debt to Equity and Growth of HBL

\begin{tabular}{|l|l|l|l|l|l|l|}
\hline & & \multicolumn{4}{|l|}{ Unstandardized Coefficients } & \multicolumn{3}{l|}{ Standardized Coefficients } \\
\hline Model & & B & Std. Error & Beta & t & Sig. \\
\hline 1 & (Constant) & 1085.554 & 43.908 & & 24.723 & 0 \\
\hline & Growth & 0.11 & 0.883 & 0.026 & 0.124 & 0.902 \\
\hline
\end{tabular}

In table 14, relationship between debt to equity and growth of HBL is measured and the significance value is 0.902 which is greater than $0.05(0.902>0.05)$. This indicates that there is no significant relationship between debt to equity and growth as null hypothesis $\mathrm{H}_{4 \mathrm{~b}}$ is accepted.

Table 15. Debt to Equity and Growth of NSBI

\begin{tabular}{|l|l|l|l|l|l|l|}
\hline & & \multicolumn{4}{|l|}{ Unstandardized Coefficients } & \multicolumn{3}{l|}{ Standardized Coefficients } \\
\hline Model & & B & Std. Error & Beta & t & Sig. \\
\hline 1 & (Constant) & 1584.821 & 100.593 & & 15.755 & 0.00 \\
\hline & Growth & -1.485 & 1.769 & -0.176 & -0.839 & 0.41 \\
\hline
\end{tabular}

Table 15 measures the relationship between debt to equity and growth of NSBI and since the significance value is 0.41 which is greater than $0.05(0.41>0.05)$. So, there exists no significant relationship between debt to equity and growth as null hypothesis $\mathrm{H}_{4}$ is accepted.

$\left(\mathrm{H}_{5}\right)$ : There is no significant relationship between leverage and business risk of sample banks.

Table 16. Debt to Equity and Business Risk of EBL

\begin{tabular}{|l|l|l|l|l|l|l|}
\hline & & \multicolumn{3}{|l|}{ Unstandardized Coefficients } & \multicolumn{3}{|l|}{ Standardized Coefficients } \\
\hline Model & & B & Std. Error & Beta & t & Sig. \\
\hline 1 & (Constant) & 1276.774 & 34.629 & & 36.87 & 0.000 \\
\hline & Risk & -1.273 & 1.537 & -0.174 & -0.828 & 0.416 \\
\hline
\end{tabular}


In table 16, relationship between debt to equity and business risk of EBL is measured and the significance value is 0.416 which is greater than 0.05 $(0.416>0.05)$. This indicates that there is no significant relationship between debt to equity and business risk as null hypothesis $\mathrm{H}_{5 \mathrm{a}}$ is accepted.

Table 17. Debt to Equity and Business Risk of HBL

\begin{tabular}{|l|l|l|l|l|l|l|}
\hline & & \multicolumn{4}{|l|}{ Unstandardized Coefficients } & \multicolumn{3}{l|}{ Standardized Coefficients } \\
\hline Model & & B & Std. Error & Beta & t & Sig. \\
\hline 1 & (Constant) & 1092.88 & 16.109 & & 67.843 & 0.000 \\
\hline & Risk & -0.275 & 0.457 & -0.127 & -0.602 & 0.553 \\
\hline
\end{tabular}

Table 17 measures the relationship between debt to equity and business risk of HBL is and the significance value is 0.553 which is greater than $0.05(0.553>0.05)$. This indicates that there is no significant relationship between debt to equity and business risk as null hypothesis $\mathrm{H}_{5 \mathrm{~b}}$ is accepted.

Table 18. Debt to Equity and Business Risk of NSBI

\begin{tabular}{|l|l|l|l|l|l|l|}
\hline & & \multicolumn{4}{|l|}{ Unstandardized Coefficients } & \multicolumn{3}{|l|}{ Standardized Coefficients } \\
\hline Model & & B & Std. Error & Beta & t & Sig. \\
\hline 1 & (Constant) & 1492.669 & 36.081 & & 41.37 & 0.000 \\
\hline & Risk & 1.967 & 1.604 & 0.253 & 1.226 & 0.233 \\
\hline
\end{tabular}

In table 18, relationship between debt to equity and business risk of NSBI is presented and as the significance value is 0.233 which is greater than 0.05 $(0.233>0.05)$. So, there is no significant relationship between debt to equity and business risk as null hypothesis $\mathrm{H}_{5 \mathrm{c}}$ is accepted.

$\left(\mathrm{Ho}_{6}\right)$ : There is no significant relationship between total debt and liquidity of sample banks.

Table 19. Total Debt and Liquidity of EBL

\begin{tabular}{|l|l|l|l|l|l|l|}
\hline & & \multicolumn{3}{l}{ Unstandardized Coefficients } & \multicolumn{3}{l|}{ Standardized Coefficients } \\
\hline Model & & B & Std. Error & Beta & t & Sig. \\
\hline 1 & (Constant) & $6.83 \mathrm{E}+07$ & $1.98 \mathrm{E}+07$ & & 3.455 & 0.002 \\
\hline & Liquidity & -708381.13 & 624140.106 & -0.235 & -1.135 & 0.269 \\
\hline
\end{tabular}

Table 19 measures the relationship between total debt and liquidity of EBL and the significance value is 0.269 which is greater than $0.05(0.269>0.05)$. This indicates that there is no significant relationship between total debt and liquidity as null hypothesis $\mathrm{H}_{6 \mathrm{a}}$ is accepted.

Table 20. Total Debt and Liquidity of HBL

\begin{tabular}{|l|l|l|l|l|l|l|}
\hline & & \multicolumn{4}{|l|}{ Unstandardized Coefficients } & \multicolumn{3}{l|}{ Standardized Coefficients } \\
\hline Model & & B & Std. Error & Beta & t & Sig. \\
\hline 1 & (Constant) & $4.02 \mathrm{E}+07$ & $1.44 \mathrm{E}+07$ & & 2.791 & 0.011 \\
\hline & Liquidity & 229526.906 & 422099.577 & 0.115 & 0.544 & 0.592 \\
\hline
\end{tabular}


Table 20 shows the relationship between total debt and liquidity of HBL and as the significance value is 0.592 which is greater than $0.05(0.592>0.05)$. So, there exists no significant relationship between total debt and liquidity as null hypothesis $\mathrm{H}_{6 \mathrm{~b}}$ is accepted.

Table 21. Total Debt and Liquidity of NSBI

\begin{tabular}{|l|l|l|l|l|l|l|}
\hline & & \multicolumn{4}{l|}{ Unstandardized Coefficients } & \multicolumn{3}{l|}{ Standardized Coefficients } \\
\hline Model & & B & Std. Error & Beta & T & Sig. \\
\hline 1 & (Constant) & $6.80 \mathrm{E}+07$ & $1.02 \mathrm{E}+07$ & & 6.668 & 0.000 \\
\hline & Liquidity & -600274.77 & 247937.039 & -0.459 & -2.421 & 0.024 \\
\hline
\end{tabular}

In table 21, relationship between total debt and liquidity of NSBI is presented and the significance value is 0.024 which is less than $0.05(0.024<0.05)$. This indicates existence of a significant relationship between total debt and liquidity as null hypothesis $\mathrm{H}_{6 \mathrm{c}}$ is rejected.

$\left(\mathrm{HO}_{7}\right)$ : There is no significant relationship between leverage and return on equity of sample banks.

Table 22. Debt to Equity and Return on Equity of EBL

\begin{tabular}{|l|l|l|l|l|l|l|}
\hline EBL & & $\begin{array}{l}\text { Unstandardized } \\
\text { Coefficients }\end{array}$ & \multicolumn{4}{|l|}{$\begin{array}{l}\text { Standardized } \\
\text { Coefficients }\end{array}$} \\
\hline $\begin{array}{l}\text { Mode } \\
1\end{array}$ & & $\mathrm{~B}$ & $\begin{array}{l}\text { Std. } \\
\text { Error }\end{array}$ & Beta & $\mathrm{t}$ & Sig. \\
\hline 1 & (Constant) & 33.32 & 5.947 & & 5.603 & 0.00 \\
\hline & Debt to equity & 0 & 0.005 & -0.024 & -0.114 & 0.91 \\
\hline
\end{tabular}

Table 22 measures the relationship between debt to equity and return on equity of EBL and the significance value is 0.91 which is greater than $0.05(0.91>0.05)$. This indicates that there is no significant relationship between debt to equity and return on equity as null hypothesis $\mathrm{H}_{7 \mathrm{a}}$ is accepted.

Table 23. Debt to Equity and Return on Equity of HBL

\begin{tabular}{|l|l|l|l|l|l|l|}
\hline & & $\begin{array}{l}\text { Unstandardized } \\
\text { Coefficients }\end{array}$ & \multicolumn{4}{|l|}{$\begin{array}{l}\text { Standardized } \\
\text { Coefficients }\end{array}$} \\
\hline $\begin{array}{l}\text { Mode } \\
1\end{array}$ & & B & $\begin{array}{l}\text { Std. } \\
\text { Error }\end{array}$ & Beta & $\mathrm{t}$ & Sig. \\
\hline 1 & (Constant) & 11.867 & 14.165 & & 0.838 & 0.411 \\
\hline & Debt to equity & 0.007 & 0.013 & 0.119 & 0.564 & 0.579 \\
\hline
\end{tabular}

In table 23, relationship between debt to equity and return on equity of HBL is measured and the significance value is 0.579 which is greater $0.05(0.579>0.05)$. This indicates that there is no significant relationship between debt to equity and return on equity as null hypothesis $\mathrm{H}_{7 \mathrm{~b}}$ is accepted. 
Table 24. Debt to Equity and Return on Equity of NSBI

\begin{tabular}{|l|l|l|l|l|l|l|}
\hline NSBI & & $\begin{array}{l}\text { Unstandardized } \\
\text { Coefficients }\end{array}$ & \multicolumn{4}{|c|}{$\begin{array}{l}\text { Standardized } \\
\text { Coefficients }\end{array}$} \\
\hline $\begin{array}{l}\text { Mode } \\
1\end{array}$ & & B & $\begin{array}{l}\text { Std. } \\
\text { Error }\end{array}$ & Beta & t & Sig. \\
\hline 1 & (Constant) & 29.05 & 6.825 & & 4.257 & 0 \\
\hline & $\begin{array}{l}\text { Debt to } \\
\text { equity }\end{array}$ & -0.006 & 0.005 & -0.285 & -1.397 & 0.176 \\
\hline
\end{tabular}

Table 24 measures the relationship between debt to equity and return on equity of NSBI and the significance value is 0.176 which is greater than $0.05(0.176>0.05)$. This indicates that there is no significant relationship between debt to equity and return on equity as null hypothesis is $\mathrm{H}_{7 \mathrm{c}}$ is accepted.

Null Hypothesis $\left(\mathrm{HO}_{8}\right)$ : There is no significant relationship between leverage and earnings per share of sample banks.

Table 25. Debt to Equity and Earnings per Share of EBL

\begin{tabular}{|l|l|l|l|l|l|l|}
\hline EBL & & \multicolumn{4}{|c|}{ Unstandardized Coefficients } & \multicolumn{3}{|c|}{ Standardized Coefficients } \\
\hline Model & & B & Std. Error & Beta & t & Sig. \\
\hline 1 & (Constant) & 34.239 & 12.868 & & 2.661 & 0.014 \\
\hline & Debt to equity & 0.042 & 0.01 & 0.669 & 4.22 & 0.000 \\
\hline
\end{tabular}

In table 25, relationship between debt to equity and earnings per share of EBL is shown and as the significance value is 0.000 which is less than $0.05(0.000<0.05)$. Thus, there exists a significant relationship between debt to equity and an earnings per share as null hypothesis H08a is rejected.

Table 26. Debt to Equity and Earnings Per Share of HBL

\begin{tabular}{|l|l|l|l|l|l|l|}
\hline HBL & & \multicolumn{4}{|l|}{ Unstandardized Coefficients } & \multicolumn{3}{|l|}{ Standardized Coefficients } \\
\hline Model & & B & Std. Error & Beta & t & Sig. \\
\hline 1 & (Constant) & -24.271 & 38.131 & & -0.637 & 0.531 \\
\hline & Debt to equity & 0.077 & 0.035 & 0.425 & 2.202 & 0.038 \\
\hline
\end{tabular}

Table 26 presents the relationship between debt to equity and earnings per share of $\mathrm{HBL}$ and as the significance value is 0.038 which is less than $0.05(0.038<0.05)$. So, there exists a significant relationship between debt to equity and earnings per share as null hypothesis $\mathrm{H}_{8 \mathrm{~b}}$ are rejected.

Table 27. Debt to Equity and Earnings Per Share of NSBI

\begin{tabular}{|l|l|l|l|l|l|l|}
\hline & & \multicolumn{4}{|l|}{ Unstandardized Coefficients } & \multicolumn{3}{|l|}{ Standardized Coefficients } \\
\hline Model & & B & Std. Error & Beta & t & Sig. \\
\hline 1 & (Constant) & 18.706 & 19.523 & & 0.958 & 0.348 \\
\hline & Debt to equity & 0.011 & 0.013 & 0.179 & 0.855 & 0.402 \\
\hline
\end{tabular}


In table 27, relationship between debt to equity and earnings per share of NSBI is presented and the significance value is 0.402 which is greater than 0.05 $(0.402>0.05)$. This indicates that there is no significant relationship between debt to equity and earnings per share as null hypothesis $\mathrm{H}_{8 \mathrm{c}}$ is accepted.

The results appear consistent with the findings of Sailaja and Madhavi (2015), Singh and Tandon (2012), Basnet (2015). The absence of significance of relationship of debt to equity with return on equity and profitability matches with the findings of Sailaja and Madhavi(2015). However, the existence of significant relationship between the debt to equity and earnings per share also matches with the findings of Sailaja and Madhavi(2015). The finding, that factors such as size of the bank, profitability, liquidity and growth are significant to the capital structure of the banks, matches with the findings of Basnet (2015).

From the analysis of financial and statistical indicators of all the sample banks, it can be concluded that banks have different financial performance in different situations. However, the theoretical approaches such as trade off theory do not appear to help explain the financial behaviour of Nepalese joint venture banks utilizing its capital.

A number of researches have been conducted in the commercial banking sector to evaluate their capital structure and capital management practices in Nepalese banking sector. However, this study conducted with focus on relationship of capital structure practices with leverage position of joint venture banks specifically has contributed something new to the existing studies done in the banking sector.

This study has also figured out that regulatory requirements also affect the leverage position in addition to the factors such as size of the bank, profitability, which adds something new to the findings of existing studies. Liquidity position and growth rate of banks have been found to be the major drivers towards the capital structure choices adopted by the joint venture banks.

\section{Concluding Remarks}

The major findings of the study derived from the comparative analysis of the sample banks and interpretation of the secondary data are summarized as follows:

The relationship of capital structure and profitability is significant for EBL in terms of ROA. However, the relationship between capital structure and profitability is not significant for HBL and NSBI in terms of ROA. In terms of ROE, there is no significant relationship between profitability and leverage of all three banks. In terms of EPS, the relationship of capital structure and profitability is significant for EBL and HBL, but, not for NSBI. This indicates that EBL has been able to derive high profits from its efficient utilization of assets and better utilization of funds. 
Thus, EBL has a stronger position in the stock market with high earnings per share. NSBI is on the lower side in terms of its profitability because of its inefficiency in utilizing its assets. So, NSBI is not able to achieve higher returns as compared to the other two banks.

Study by Sailaja and Madhavi (2015), however, showed a significant relationship of leverage with EPS only and insignificant relationship with ROA and ROE.

Among the six main determinants of capital structure analyzed in the study, size, profitability, liquidity and growth are significant determinants. Profitability measured by return on assets and size of the banks measured by total assets is negatively correlated to the leverage measured by debt to equity. There is no significant relationship between the business risk of the sample banks and its leverage measured by the debt to equity ratio.

Similar study done by Basnet (2015) had the conclusion that factors such as size of the bank, profitability, liquidity and growth are significant to the capital structure of the bank. However, their study shows significant relationship between risk of banks and its leverage which is different from our findings.

Out of the three joint venture banks taken into consideration for this study, Everest Bank Limited has been found to be better in terms of profitability, Himalayan Bank Limited is better in terms of stability and Nepal SBI Bank is more prone to risk but has sufficient liquidity at present to manage its operations.

A similar study by Singh and Tandon (2015) based on comparative study of SBI and ICICI bank concludes that use of more debt fund as compared to equity decreasesthe weighted average cost of capital. This in turn, increases the return of shareholders, whereas, our study regards the more use of debt as risky which may or may not derive higher returns. This study has helped to provide a mirror view into important factors such as debt equity ratio, return on shareholder's equity, earning per share, which are of a bigger concern to the shareholders. Besides, analysis of the capital structure management practices obtained through the study will enable the banks to understand ways to protect the interest of the capital providers andensure payment of dividend. This will then gear benefit in optimizing return on investment and enhance the bank's ability to raise new funds.

This study has figured out that regulatory requirements also affect the leverage position in addition to the other factors such as size of the bank, profitability. Relationship of regulatory requirements with leverage of banks had not been addressed by the earlier studies and this paper adds something new to the existing literature based on its findings. 
The study is not free from limitations, as the study covers only the financial aspects. It is conducted solely on the basis of secondary data of the past six years quarterly figures which may not suffice the full-fledged study of the topic. However, the outcome of this comparative study is expected to help the other researchers or students who are interested in understanding the capital structure management of the joint venture banks. This study provides the future researchers with a comparative view into the capital management practices of the bank. Besides, it also provides an insight into the factors detrimental in choosing appropriate amount of equity and debt capital for the bank.

\section{REFERENCES}

Aivazian, V., Booth, L., Kunt, A. D., \& Maksimovic, V. (n.d.). Capital structures in developing Countries.

Ajanthan, A. (2013, June). Determinants of capital structure: Evidence from hotel and restaurant companies in Sri Lanka. International Journal of Scientific and Research Publications, 3(6), pp 01-08

Akter, A., Parvin, A., \& Easmin, S. (2015, March-April). A comparative analysis of capital structure between banking and non-banking financial institutions of Bangladesh. IOSR Journal of Economics and Finance, 6(2), pp 01-08, doi:10.9790/5933-06220108

Aremu, M. A., EKPO, I. C., Mustapha, A. M., \& Adedoyin, S. I. (2013, July). Determinants of capital structure in Nigerian banking sector. Internationsl Journal of Academic Research in Economics and Management Science, 2(4), 27-43.

Baral, K. J. (2004, December). Determinants of capital structure: A case study of listed companies of Nepal. Journal of Nepalese Business Studies, 1(1), 01-13.

Basnet, A. (2015). Capital structure choice of financial firms: Evidence from Nepalese commercial banks.

Gropp, R., \& Heider, F. (2009, September). The determinants of bank capital structure. ECB Working Paper Series(1096).

Hossain, M., \& Yakub, K. M. (2014, April). Impact of firm characteristics on capital structure of banking industry of Bangladesh. IOSR Journal of Business and Management, 16(4), pp 17-25.

Ibrahim, M. (2014). A comparative performance of two banks in United Arab Emirates. Research Journal of Finance and Accounting, 5(24). 
James, E. F., \& Moshi, J. (2014). Capital structure and firm performance:Evidence from commercial banks in Tanzania. Research Journal of Finance and Accounting, 5(14).

Juca, M. N., De Sousa, A. F., \& Fishlow, A. (2012, January). Capital structure determinants of Brazilian and North American banks. International Journal of Business and Commerce, 1(5), pp 44-63.

Marimuthu, M. (2009). Corporate restructuring, firm characteristics and implications on capital structure. International Journal of Business and Management, 4(1).

Phor, M. (2014, May). Capital structure: A comparative study of SBI and ICICI. Abhinav International Monthly Referred Journal of Research in Management and Technology, 3(5).

Sailaja, V., \& Madhavi, N. B. (2015). Comparison of capital structure of public sector banks and private sector banks and its effect on bank's profitability. International Journal of Management and Social Science Research, 1(11), pp 176-183.

Salehi, M., \& Biglar, K. (2009, January ). Study of the relationship between capital structure measures and performance: Evidence from Iran. International Journal of Business and Management, 4(1), pp 97-103.

San, O. T., \& Heng, T. B. (2011, February). Capital structure and corporate performance of Malaysian construction sector. Center for Promoting Ideas, 1(2), pp 28-36.

Shala, A., Ahmeti, S., Vlora, B., \& Perjuci, E. (2014, June). The factors that determine capital structure among insurance comapnies in Kosovo: Empirircal analysis. Academic Journal of Interdisciplinary Studies, 3(2). doi:10.5901/ajis.2014.v3n2p43

Singh, A. B., \& Tandon, P. (2012). Comparative analysis of capital structure of banking companies with special preference to State Bank of India and ICICI Bank. International Journal of Research in Commerce and Management, $3(10)$.

Skopljak, V., \& Luo, R. H. (2012, March). Capital structure and firm performace in financial sector: Evidence from Australia. Asian Journal of Finance and Accounting, 4(1).

Strahan, P. E., \& Cebenoyan, A. S. (2001, October). Risk management, capital structure and lending at banks. Wharton Financial Institutions Center. 
Taani, K. (2013). Capital study effects on banking performance. Internal Journal of Economics, Finance and Management Science, 1(5), pp 227-233.

Tamulyte, J. (2012, January). The determinants of capital structure in Baltic States and Russia. PEI Electronic Publications.

Timsina, Sujata (2015, September). Comparative Study of Capital Structure Management of Joint Venture Banks of Nepal, AIM, Pokhara University

Velnampy, T., \& Niresh, J. A. (2012). The relationship between capital structure and profitability. Global Journal of Management and Business Research, $12(13)$.

Vitor, D. A., \& Badu, J. (2012, March). Capital structure and performace of listed banks in Ghana. Global Journal of Human Social Science, 12(5).

Zeitun, R., \& Tian, G. (2007, December ). Capital structure and corporate performance: Evidence from Jordan. Australasian Accounting, Business and Finance Journal, 1(4), pp 40-60.

Research paper on Capital Structure Management of Joint Venture Banks of Nepal, May 2016

Aivazian, V., Booth, L., Kunt, A. D., \& Maksimovic, V. (n.d.). Capital structures in developing Countries.

Ajanthan, A. (2013, June). Determinants of capital structure: Evidence from hotel and restaurant companies in Sri Lanka. International Journal of Scientific and Research Publications, 3(6), pp 01-08

Akter, A., Parvin, A., \& Easmin, S. (2015, March-April). A comparative analysis of capital structure between banking and non-banking financial institutions of Bangladesh. IOSR Journal of

Economics and Finance, 6(2), pp 01-08, doi:10.9790/5933-06220108

Aremu, M. A., EKPO, I. C., Mustapha, A. M., \& Adedoyin, S. I. (2013, July). Determinants of capital structure in Nigerian banking sector. Internationsl Journal of Academic Research in Economics and Management Science, 2(4), $27-43$.

Baral, K. J. (2004, December). Determinants of capital structure: A case study of listed companies of Nepal. Journal of Nepalese Business Studies, 1(1), 01-13.

Basnet, A. (2015). Capital structure choice of financial firms: Evidence from Nepalese commercial banks. 
Gropp, R., \& Heider, F. (2009, September). The determinants of bank capital structure. ECB Working Paper Series(1096).

Hossain, M., \& Yakub, K. M. (2014, April). Impact of firm characteristics on capital structure of banking industry of Bangladesh. IOSR Journal of Business and Management, 16(4), pp 17-25.

Ibrahim, M. (2014). A comparative performance of two banks in United Arab Emirates. Research Journalof Finance and Accounting, 5(24).

James, E. F., \& Moshi, J. (2014). Capital structure and firm performance:Evidence from commercial banks in Tanzania. Research Journal of Finance and Accounting, 5(14).

Juca, M. N., De Sousa, A. F., \& Fishlow, A. (2012, January). Capital structure determinants of Brazilian and North American banks. International Journal of Business and Commerce, 1(5), pp 44-63.

Marimuthu, M. (2009). Corporate restructuring, firm characteristics and implications on capital structure. International Journal of Business and Management, 4(1).

Phor, M. (2014, May). Capital structure: A comparative study of SBI and ICICI. Abhinav International Monthly Referred Journal of Research in Management and Technology, 3(5).

Sailaja, V., \& Madhavi, N. B. (2015). Comparison of capital structure of public sector banks and private sector banks and its effect on bank's profitability. International Journal of Management and Social Science Research, 1(11), pp $176-183.23$

Research paper on Capital Structure Management of Joint Venture Banks of Nepal, May 2016

Salehi, M., \& Biglar, K. (2009, January ). Study of the relationship between capital structure measures and performance: Evidence from Iran. International Journal of Business and Management, 4(1), pp 97-103.

San, O. T., \& Heng, T. B. (2011, February). Capital structure and corporate performance of Malaysian construction sector. Center for Promoting Ideas, 1(2), pp 28-36.

Shala, A., Ahmeti, S., Vlora, B., \& Perjuci, E. (2014, June). The factors that determine capital structure among insurance comapnies in Kosovo: Empirircal analysis. Academic Journal of Interdisciplinary Studies, 3(2). doi:10.5901/ajis.2014.v3n2p43 
Singh, A. B., \& Tandon, P. (2012). Comparative analysis of capital structure of banking companies with special preference to State Bank of India and ICICI Bank. International Journal of Research in Commerce and Management, $3(10)$.

Skopljak, V., \& Luo, R. H. (2012, March). Capital structure and firm performace in financial sector: Evidence from Australia. Asian Journal of Finance and Accounting, 4(1).

Strahan, P. E., \& Cebenoyan, A. S. (2001, October). Risk management, capital structure and lending at banks. Wharton Financial Institutions Center.

Taani, K. (2013). Capital study effects on banking performance. Internal Journal of Economics, Finance and Management Science, 1(5), pp 227-233.

Tamulyte, J. (2012, January). The determinants of capital structure in Baltic States and Russia. PEI Electronic Publications.

Timsina, Sujata (2015, September). Comparative Study of Capital Structure Management of Joint Venture Banks of Nepal, AIM, Pokhara University

Velnampy, T., \& Niresh, J. A. (2012). The relationship between capital structure and profitability. Global Journal of Management and Business Research, 12(13).

Vitor, D. A., \& Badu, J. (2012, March). Capital structure and performace of listed banks in Ghana. Global Journal of Human Social Science, 12(5).

Zeitun, R., \& Tian, G. (2007, December ). Capital structure and corporate performance: Evidence from Jordan. Australasian Accounting, Business and Finance Journal, 1(4), pp 40-60 